Available Online : https://proceeding.researchsynergypress.com/index.php/cset/index

RSF Conference Series: Engineering and Technology

ISSN 2809-6843 (Online) | 2809-6878 (Print)

Volume 1 Number 1 (2021): 521-526

\title{
Potential of Paitan (Tithonia diversifolia) and Cow Manure for Available Nutrients Supply on Sandy Beach Soil
}

\author{
Lelanti Peniwiratri' ${ }^{1}$, Miseri Ruslan Afany² \\ 1, 2 Department of Soil Science, Faculty of Agriculture, UPN “Veteran” Yogyakarta, Indonesia
}

\begin{abstract}
The primary macronutrients are required in large amounts for optimum plant growth. Sandy beach soil that is widely distributed, has a granular structure and is poor in primary macronutrients. Cow manure can improve the struktur of soil and Paitan (Tithonia diversifolia) can increase the availability of primary macro nutrients. This study aims to determine the effect of cow manure and Paitan (Tithonia diversifolia) on the nutrient availability of sand beach soil. The study used a completely randomized design (CRD) with 2 factors, the first factor was the dose of cow manure consisting of 3 levels $0 ; 2.5$ and $5 \%$ of the weight of the soil. The second factor is the dose of Paitan (Thitonia diversifolia) which consists of 4 levels of $0 ; 2.5 ; 5$ and $7.5 \%$. of soil weight To determine the effect of treatment, variance analysis (ANOVA) was used and followed by a follow-up test using Duncan Multiple Range Test (DMRT) at a test level of 5\%. The results showed that the application of cow manure and Paitan (Thitonia diversifolia) had a significant effect on increasing $\mathrm{N}$ available, $\mathrm{P}$ available and $\mathrm{K}$ available nutrients. The application of $5 \%$ cow manure and Paitan (Thitonia diversifolia) $5 \%$ has the potential to increase $\mathrm{N}$ available, $\mathrm{P}$ available and $\mathrm{K}$ available. sand beach soil is the highest
\end{abstract}

Keywords: Nutrients, Manure, Paitan, Sand beach

This is an open access article under the CC-BY-NC license

\section{INTRODUCTION}

Nitrogen, Phosphorus and Potassium are primary macronutrients that are required in large amounts for optimum plant growth. Sand Beach Soil has the potential as a medium for plant growth because it is still very wide and has not been widely used, but this soil has serious obstacles both in terms of physical and chemical aspects, especially in the provision of nutrients. (Syukur dan Harsono. 2008). Cow manure can improve the physical and chemical properties of Sand Beach Soil, while Paitan (Tithonia diversifolia) can increase the availability of primary macro nutrients so that the application of cow manure and Tithonia diversifolia is expected to overcome the constraints of Sand Beach Soil and increase the availability of primary macro nutrients (Purwani, 2011). This study aims to determine the effect of cow manure and Paitan (Tithonia diversifolia) on the nutrient availability of sand beach soil.

\section{LITERATURE REVIEW}

The ability of the soil to provide nutrients can reflect the level of soil fertility and is positively correlated with the yield of cultivated plants. On the other hand, the level of soil fertility is negatively correlated with the need for fertilizer or it can be interpreted that the lower the level of soil fertility, the higher the use of fertilizer needs to be added. the application of $\mathrm{N}, \mathrm{P}$ and $\mathrm{K}$ nutrients often shows a significant effect. When the supply of $\mathrm{N}$ is sufficient, plant leaves grow large and expand the surface available for photosynthesis, accelerating the conversion of carbohydrates into proteins which are then converted into protoplasm, serving as vital ingredients for various enzymes that guide all plant metabolic processes. In addition, Phosphorus (P) nutrients also play a role in cell division, fat formation, seed filling, fertilization and seed ripening, root development, increasing plant resistance to pests and diseases. Potassium (K) is an important element that is hygroscopic (easy to absorb and retain water). Elemental $\mathrm{K}$ is usually found in leaf stomata. With its hygroscopic nature, Potassium is able to optimize the supply of water needed in the processes of transpiration, photosynthesis,absorption, and transportation of nutrients in the plant. Potassium nutrient deficiency causes stunted plants, weak (not upright), the process of transporting respiratory nutrients and photosynthesis is disrupted which in turn reduces production. 
The Sandy Beach Soil is one of the soil groups that are mostly found on dry land, has the potential as a medium for plant growth, this soil has high levels of nitrogen, phosphorus and potassium nutrients in total, but the available nutrient levels of N, P, K are low. This condition as a result of the development of young soil causes the soil to be dominated by sand texture, single grain structure to crumbs, loose consistency when dry, has low moisture holding capacity and high-water permeability. This sandy texture and single grain structure to crumbs causes the space between grains to be large, water holding capacity is low and water escape ability is high, so the ability to provide essential nutrients is reduced and soluble elements will be easily lost and not available to plants (Sunardi and Sarjono, 2007). The low content of clay minerals and organic matter in this soil causes the formation of colloidal soil complexes which are usually formed due to the association between clay minerals and organic matter in the formation of clayhumus complexes, thereby reducing the metabolic activity of microorganisms, cation exchange capacity and soil capacity retain water and available nutrients. (Atmojo, 2003).

To overcome these obstacles, it is necessary to make improvements so that the sandy beach soil can be used as a medium for plant growth. Improvements were made by adding organic matter in the form of cow manure and paitan (Tithonia diversifolia) so as to increase soil colloid and improve soil structure quality. Improved soil structure causes a balance of pore space of water and soil air that is more favorable for plant growth. The role of organic matter on the availability of nutrients in the soil cannot be separated from the mineralization process which is the final stage of the process of overhauling organic matter. Organic matter is a source of energy for soil macro and micro fauna. The addition of organic matter in the soil will cause the activity and population of microbiology in the soil to increase, especially those related to the activity of decomposition and mineralization of organic matter. (Atmojo, 2003).

Cow manure is fertilizer that comes from cattle pens, either in the form of solid manure mixed with food residue or urine. All waste products from cattle in the form of fresh or composted solid or liquid have natural properties and do not damage the soil, providing macro (nitrogen, phosphorus, potassium, calcium, and sulfur) and micro elements (iron, zinc, boron, cobalt, and molybdenium). Cow manure is able to improve soil structure by aggregating sandy soil so that it can improve aeration quality, improve soil drainage, and increase the ability of the soil to store water and nutrients. Improving the structure of the sandy beach soil will have an impact on increasing the availability of nutrients in the soil through the mineralization process which is the final stage of the organic matter reform process. In the mineralization process, plant nutrient minerals will be completely released $(\mathrm{N}, \mathrm{P}, \mathrm{K}, \mathrm{Ca}, \mathrm{Mg}$ and $\mathrm{S}$, as well as micro nutrients) so that it will increase the cation exchange capacity (CEC) (Syukur and Harsono,2008).

Paitan (Tithonia diversifolia) is an annual weed that deserves to be used as a source of nutrients for plants (Opala, et al., 2009 Crespo, et al 2011). The nutrient content of dry Tithonia leaves is $3.50-4.00 \%$ N; 0.35 - 0.38\% P; $3.50-4.10 \% \mathrm{~K} ; 0.59 \% \mathrm{Ca}$; and 0.27\% Mg (Hartatik 2007). Purwani (2011) reported that Tithonia has a nutrient content of $2.7-3.59 \% \mathrm{~N} ; 0.14-0.47 \% \mathrm{P} ; 0.25-4.10 \% \mathrm{~K}$. The advantage of using Paitan (Tithonia diversifolia) as organic material for soil improvement is the abundance of biomass production, wide adaptation and ability to grow on residual land or on marginal land. The parts of Paitan weed that can be used as green manure are the stems and leaves. Utilization of Paitan (Tithonia diversifolia) as a source of nutrients, which can be used in the form of fresh green manure, liquid green manure, or compost (Hakim et al., 2012). Dry Tithonia biomass production (stem + leaves) ranged from 2.0 - 3.9 tonnes/ha at eight months after cuttings planting (King'ara 1998). The combination of Paitan (Tithonia diversifolia) and cow manure is expected to overcome the low availability of nutrients in sandy beach soils.This study aims to determine the effect of cow manure and Paitan (Tithonia diversifolia) on nutrient availability in sandy beach soil.

\section{RESEARCH METHODOLOGY}

The research was conducted carried out at the Green House in Srandakan, Bantul Regency, Yogyakarta. Soil analysis was carried out in the Laboratory of Chemistry and Soil Fertility, Soil Science study program, Faculty of Agriculture, UPN Veteran Yogyakarta. This study used a completely randomized design (CRD) with 2 factors, the first factor was the dose of cow manure consisting of 3 levels, i.e., $0 \%$ (S0); 2.5\% (S1) and 5\% (S2) of the weight of the soil. The second factor is the dose of Paitan (Tithonia diversifolia) which consists of 4 levels, i.e., $0 \%$ (D0); $2.5 \%$ (D1); 5\% (D2); and 7.5\% (D3) of the weight of the soil. Each treatment was repeated 3 times, so there were 36 treatments. The sandy beach soil from Samas Beach, as 
in field conditions (with known moisture content) was taken randomly at a depth of 0-20 cm, then the soil was composited and air-dried.

Table 1. Physical and chemical properties of sandy beach soil

\begin{tabular}{lll}
\hline Soil properties & Values & Rate * \\
\hline C - Organik (\%) & 0,0198 & Very low \\
N - Total (\%) & 0,092 & Low \\
N - Available (\%) & 0,0073 & Very low \\
P - Available (ppm) & 9,946 & L ow \\
K - Available (me\%) & 0,240 & Very low \\
pH H20 & 7,15 & Neutral \\
KPK (me\%) & 4,346 & Low \\
Texture class & & sand \\
Sand (\%) & 98,00 & \\
Silt (\%) & 0,1 & \\
Clay (\%) & 1,9 & \\
\end{tabular}

*Balittanah, 2009

Table 2. Chemical compositions of cow manure and Paitan (Tithonia diversifolia)

\begin{tabular}{lcl}
\hline Organic Matter & Cow Manure & Paitan \\
\hline C - Organic (\%) & 13,071 & 36,392 \\
N - Total (\%) & 1,423 & 3,159 \\
P - Total (\%) & 0,184 & 0,512 \\
K - Total (\%) & 0,936 & 1,581
\end{tabular}

Furthermore, the soil is filtered using a $2 \mathrm{~mm}$ diameter sieve, put into a pot, equivalent to $5.1 \mathrm{~kg}$ of winddried soil. Treatment materials in the form of cow manure and Paitan fertilizer (Tithonia diversifolia) were also obtained from Samas Beach.

The cow manure that has been air dried is filtered with a diameter of $2 \mathrm{~mm}$. While Paitan (Tithonia diversifolia) first chopped with a knife until the size of $1-2 \mathrm{~cm}$. Cow manure is given at a rate of $0 \% ; 2.5 \%$; and $5 \%$ or equal to $0 \mathrm{~g} /$ polybag; $254.9 \mathrm{~g} /$ polybag and $509.8 \mathrm{~g} /$ polybag. Furthermore, Tithonia diversifolia is given at a dose of $0 \% ; 2.5 \% ; 5 \%$ and $7.5 \%$ or equal to $0 \mathrm{~g} /$ polybag; $254.9 \mathrm{~g} /$ polybag; $509.8 \mathrm{~g} / \mathrm{polybag}$ and $764.7 \mathrm{~g} /$ polybag. After being mixed evenly between the soil, cow manure and Paitan (Tithonia diversifolia) are the given water until a field capacity condition is reached. Soil moisture is maintained of field capacity conditions, namely by weighing the water. The amount of water is determined by weighing the experiment pots every day. The difference between the weight and contents at the time of weighing with the original weight constitutes the weight of water that must be added. The soil that had been added with cow manure and Tithonia diversifolia was incubated for 1 month, then an analysis of available nutrients is carried out of sandy beach soil. To determine the effect of treatment on research parameters using analysis of variance, while to determine the comparison between treatments used Duncan's Multiple Range Test (DMRT) with a significant difference of 5\%. (Gomes and Gomes, 2005)

Methodology explains about what research method used, how the data collected and proceed quantitatively or qualitatively to get more explanation in the result and discussion.

\section{FINDING AND DISCUSSION}

The results of soil analysis at the research site (table 1) show that the sandy beach soil used in this study has a very low C-Organic content of $0.0198 \%$. This soil is dominated by the sand fraction (98\%) which causes the soil to have a high porosity, susceptibility to leaching and the ability to hold water and nutrients 
is low. The low content of clay minerals and organic matter also prevents the formation of colloidal soil complexes which are usually formed due to the association between clay minerals and organic matter in forming clay-humus complexes. This condition causes the low cation exchange capacity (CEC) of soil $(4.346 \mathrm{me} \%)$ and the availability of nutrients including $\mathrm{N}$ - total is low with a value of $0.22 \%, \mathrm{~N}$-available nutrients are $0.007 \%$ (very low), $\mathrm{P}$-available is $9.946 \mathrm{ppm}$ (low) and $\mathrm{K}$-available at $0.240 \mathrm{me} \%$ (very low). This soil also has a pH (H2O) of 7.15 which is classified as neutral. The low CEC on this soil requires the addition of fertilizer as a soil enhancer. In this case, the use of manure and Paitan (Tithonia diversifolia) is expected to increase the fertility of the sandy beach soil, especially in the supply of nutrients.

From table 2 it can be seen that Paitan and Cow Manure contain very high levels of C-Organic, each of $36.392 \%$ for Paitan and $13.071 \%$ of manure. In addition, the two fertilizers also contain high levels of nutrients, respectively for Paitan $\mathrm{N}$ of $3.159 \%$, P of $0.512 \%$ and $\mathrm{K}$ of $1.581 \%$, while for cow manure each $\mathrm{N}$ is $1.423 \%, \mathrm{P}$ is $0.184 \%$ and $\mathrm{K}$ of $0.936 \%$. These data indicate that Paitan (Tithonia diversifolia) and cow manure have the potential to be used as ingredients for improving sandy beach soil.

The response of the nutrient availability of sandy beach soil due to the influence of cow manure and Paitan green manure is presented in table 3.

The cation exchange capacity of soil is the ability of soil colloids to absorb and exchange cations. The total cation exchange capacity is the sum of the negative charges of the soil from the colloidal surface of the soil which is the cation - cation exchange site. Cation exchange capacity is expressed in milliequivalents per 100 grams of soil.

Table 3. Effect of cow manure and Paitan (Tithonia diversifolia) to CEC, $\mathrm{N}$ available, $\mathrm{P}$ available and $\mathrm{K}$ available of sandy beach soil

\begin{tabular}{llcll}
\hline Treatment & $\begin{array}{l}\text { CEC } \\
\text { (me\%) }\end{array}$ & $\begin{array}{c}\text { N-available } \\
\text { (\%) }\end{array}$ & $\begin{array}{l}\text { P-available } \\
\text { (ppm) }\end{array}$ & $\begin{array}{c}\text { K-available } \\
\text { (me\%) }\end{array}$ \\
\hline \multicolumn{1}{c}{ Paitan } & & & & \\
\hline $\mathbf{0 \%}$ (D0) & $4,8216 \mathrm{r}$ & $0.024 \mathrm{r}$ & $11,1919 \mathrm{r}$ & $0,3438 \mathrm{r}$ \\
$\mathbf{2 , 5 \%}$ (D1) & $5,8995 \mathrm{q}$ & $0.029 \mathrm{q}$ & $14,6067 \mathrm{q}$ & $0,8476 \mathrm{q}$ \\
$\mathbf{5 \%}$ (D2) & $7,0404 \mathrm{p}$ & $0.037 \mathrm{p}$ & $17,6819 \mathrm{p}$ & $1,1574 \mathrm{p}$ \\
$\mathbf{7 , 5 \%}$ (D3) & $6,9809 \mathrm{p}$ & $0.034 \mathrm{p}$ & $18,2222 \mathrm{p}$ & $1,1486 \mathrm{p}$ \\
\hline Cow Manure & & & & \\
\hline $\mathbf{0 \%}$ (S0) & $5,1821 \mathrm{c}$ & $0,0101 \mathrm{c}$ & $12,5172 \mathrm{~b}$ & $0,4406 \mathrm{~b}$ \\
$\mathbf{2 , 5 \%}$ (S1) & $5,9672 \mathrm{~b}$ & $0,0126 \mathrm{~b}$ & $15,0639 \mathrm{~b}$ & $0,7046 \mathrm{~b}$ \\
$\mathbf{5 \%}$ (S2) & $7,4076 \mathrm{a}$ & $0,0165 \mathrm{a}$ & $18,6958 \mathrm{a}$ & $1,4778 \mathrm{a}$ \\
\hline Interaction & $(-)$ & $(-)$ & $(-)$ & $(-)$ \\
\hline
\end{tabular}

Description: Avarage followed by the same letter in the same column shows there is non-significant nt based on Duncan's Multiple Range Test at the level 5\% level. (-) there is no interaction

From table 3, it can be seen that both the treatment of cow manure and Paitan (Tithonia diversifolia) had a significant effect on increasing the CEC of sandy beach soil, but there is no interaction. The CEC increased significantly compared to the control as the dose of cow manure and Paitan (Tithonia diversifolia) given increased. Giving cow manure 5\% of the weight of the soil (S2) has a significant effect on giving the best results. Giving Paitan (Tithonia diversifolia) as much as 5\% (D2) also gave the best increase in CEC, giving a dose above it at 7.5\% (D3) showed results that is not significantly different. The treatment of Tithonia diversifolia had a significant effect on increasing the CEC of sandy beach soils. This means that Paitan (Tithonia diversifolia) plays a role in increasing the CEC of sandy beach soils. The CEC increased significantly compared to the control as the dose of Tithonia diversifolia was increased. Giving Paitan 
(Tithonia diversifolia) as much as 5\% (D2) gave the best increase in the CEC. Giving a dose of Tithonia diversifolia above it (D3) showed an increase in the CEC which was not significantly different. The increase in the CEC occurs because the application of cow manure and Paitan can add colloidal material which can increase the soil CEC. One of the factors that affect soil CEC is colloid material, either inorganic colloid or clay or organic colloid or humus. That one of the factors that affect the value of soil CEC is the humus content of the soil and the type of clay mineral.

Nitrogen $(\mathrm{N})$ is a nutrient that plants need in large amounts for the entire growth process. In plants, nitrogen serves as the main component of proteins, hormones, chlorophyll, vitamins, and enzymes essential for plant life. Atmospheric N2 must be converted to become available to plants in order to be used by plants (Nariratih et al,2013). From table 3, it can be seen that both the treatment of cow manure and Paitan (Tithonia diversifolia) significantly affected the increase in $\mathrm{N}$-available in sandy beach soil, but there is no interaction between the two. This means that both cow manure and Tithonia play a role in increasing $\mathrm{N}$-available sandy beach soil. From table 3, it is known that the application of both cow manure and Paitan was able to significantly increase the available $\mathrm{N}$-available sand beach compared to the control. The available $\mathrm{N}$ increases with the increase in the dose of cow manure and Paitan given. Giving cow manure as much as 5\% (S2) gave the best increase in $\mathrm{N}$ available. The treatment of Paitan 5\% (D2) significantly increased the highest available of $\mathrm{N}$, the above dose (D3) showed no significant difference. This increase in available $\mathrm{N}$-available sandy beach soil is due to the increased supply of organic $\mathrm{C}$ from cow manure and Paitan. Carbon is a source of food for soil microorganisms, the presence of organic $\mathrm{C}$ in the soil will stimulate the activities of microorganisms so as to increase the process of soil decomposition and also reactions that require the assistance of microorganisms, for example the fixation of N. (Nariratih et.al .,2013) explained that an increase in soil organic $\mathrm{C}$ can indirectly increase the available $\mathrm{N}$ content of the soil. In addition, the increase in available of $\mathrm{N}$ was also influenced by the increase in CEC caused by the application of cow manure and Paitan. The higher the CEC value, the more cations it absorbs, including $\mathrm{NH} 4+$.

Phosphorus is needed by plants for the formation of the vegetative phase including stimulating root development, compiling cell components formed from protein compounds and circulating energy to all parts of the plant and in the generative phase to form flower organs, fruit and seeds. (Wahyudi. 2016).From table 3, it can be seen that the application of cow manure and Paitan (Tithonia diversifolia) significantly increased the available P-available in coastal sandy soil, but there is no interaction between the two. The available P increased with increasing doses of cow manure and Paitan given. Giving cow manure as much as 5\% (S2) gave the best increase in available P, giving Paitan as much as 5\% (D2) had a significant effect on increasing the highest available $\mathrm{P}$ of soil, but giving a dose above $7.5 \%$ of the weight of the soil (D3) actually reduce the results and show no significant difference. The increase in available $P$ in coastal sandy soils can indirectly come from the release of P-adsorption due to organic acids from the decomposition process of cow manure and Paitan, partly from the release of $\mathrm{P}$ through the mineralization process.

$\mathrm{K}$-available in the soil dissolves very quickly and is quickly absorbed by plants. Potassium plays an important role in physiological processes in carbohydrate metabolism, starch formation and breakdown, accelerates the growth and development of meristem tissue and regulates the opening and closing of stomata. Table 3 shows that the application of cow manure and Paitan (Tithonia diversifolia) has a significant effect on increasing the available K-available Sand Beach, but there is no interaction between the two. The available $\mathrm{K}$ increases with the increase in the dose of cow manure and Paitan given. Giving cow manure as much as $5 \%$ (S2) gave the best increase in available $\mathrm{K}$, as well as giving Paitan (Tithonia diversifolia) $5 \%$ of the weight of the soil (D2) had a significant effect on increasing K-available the best soil, giving a dose above it of $7.5 \%$ (D3) does not have a significant effect. The increase in K-available in coastal sandy soils can indirectly come from the release of K-adsorption due to organic acids from the decomposition process of cow manure and Paitan, partly the release of $\mathrm{K}$ through the mineralization process.

\section{CONCLUSION AND FURTHER RESEARCH}

Application of cow manure has a significant effect on increasing available $\mathrm{N}$, available $\mathrm{P}$ and available $\mathrm{K}$ in coastal sandy soil. Giving Paitan (Tithonia diversifolia) significantly increased available N, available P and 
available K in Beach Sand Soil. The application of 5\% cow manure and Paitan (Tithonia diversifolia) 5\% gave the highest response of $\mathrm{N}$ - available, available $\mathrm{P}$ and $\mathrm{K}$ available.

\section{Acknowledgement}

The authors would like to thank the Institute for research and Community Service at Universitas

Pembangunan Nasional Veteran Yogyakarta, Indonesia, for providing funds for this research

\section{REFERENCES}

Atmojo, S. 2003. "Peranan Bahan Organik terhadap Kesuburan Tanah dan Upaya Pengelolaannya". Pengukuhan Guru Besar. Surakarta: Fakultas Pertanian Universitas Sebelas Maret.

Balittanah. 2009. Petunjuk Teknis Edisi 2 Analisis Kimia Tanah, Tanaman, Air, Dan Pupuk. Balai Penelitian Tanah. Bogor.

Crespo, G., T.E. Ruiz, and J. Alvarez. 2011. Effect of green manure from Tithonia (T. diversifolia) on the establishment and production of forage of P. purpureumcv. Cuba CT-169 and on some soil properties. J. Agric. Sci. 45:79-82.

Gomes, K.A.and A.A.Gomes. 2005. Prosedur Statistik untuk penelitian Pertanian Terjemahan Sjamsuddin,F dan Baharsyah,J.S (edisi kedua) UI Press.Jakarta

Hakim, N., Agustian, and Y. Mala. 2012. Application of organic fertilizer Tithonia plus to control iron toxicity and reduce commercial fertilizer application on new paddy field. J. Trop. Soils 17:135-142.

Hartatik, W. 2007. Tithonia diversifolia sumber pupuk hijau. Warta Penelitian dan Pengembangan Pertanian $29(5): 3$ - 5.

King'ara, G. 1998. Establishment methods of Tithonia diversifolia from seeds and cuttings.Report for diploma certificate. Rift Valley Technical Training Institute.

Nariratih, I., Damanik, MMB., dan Sitanggang, G. 2013. "Ketersediaan Nitrogen pada Tiga Jenis Tanah Akibat Pemberian Tiga Bahan Organik dan Serapannya pada Tanaman Jagung". Jurnal Online Agroekoteknologi. Vol. 1, No. 3. Medan.

Opala, P.A., C.O. Othieno, J.R. Okalebo, and P.O. Kisinyo.2009. Effects of combining organic materials with inorganic phosphorus source on maize yield and financial benefits in western Kenya. Exp. Agric. 46:23-34

Purwani, J. 2011. Pemanfaatan Tithonia diversifolia (Hamsley) A. Gray untuk perbaikan tanah. Balai Penelitian Tanah. 253 - 263.

Sunardi dan Y. Sarjono. 2007. Penentuan Kandungan Unsur Makro Pada Lahan Pasir Pantai Samas Bantul Dengan Metode Analisis Aktivasi Neutron (AAN). Prosiding PPI- PDIPTN 2007 BATAN p: 123-129.

Syukur dan Harsono. 2008. Pengaruh pemberian pupuk kandang dan NPK terhadap beberapa sifat kimia dan fisika tanah pasir pantai Samas Bantul. Jurnal Ilmu Tanah dan Lingkungan 8: 138-145.

Wahyudi, I. Fikdalillah. M. Basir. 2016. Pengaruh Pemberian Pupuk Kandang Sapi Terhadap Serapan Fosfor Dan Hasil Tanaman Sawi Putih (Brassica Pekinensis) Pada Entisols. e-J. Agrotekbis 4 (5) : 491- 499. 